\title{
O AKTYWNOŚCI OSÓB STARSZYCH SŁÓW KILKA
}

\begin{abstract}
Streszczenie
Ostatnie lata przyniosty wzmożone działania państwa na rzecz tworzenia $i$ wdrażania aktywnej polityki społecznej. Obserwuje się działania majace integrować społeczności osób zagrożonych wykluczeniem oraz aktywności mające przywrócić społeczeństwu grupy już zmarginalizowane, wykluczone. Jedna z takich społeczności, w stosunku do których aktywizuje się dziatania polityki społecznej, są ludzie starzy. Sama populacja seniorów jest wewnętrznie mocno zróżnicowana, stąd oczekiwać należałoby zróżnicowanych ofert aktywizacyjnych. Czy jednak tak jest $w$ rzeczywistości? Czy podejmowane formy pracy z osobami i na rzecz osób starszych sq na tyle właściwe, że odnosza zamierzony skutek? Co więcej: jeżeli jest tak dobrze, to dlaczego jest tak źle? Gdzie należy szukać źródel niepowodzeń? To tylko niektóre pytania, na które - wprawdzie pobieżnie - postara się odpowiedzieć niniejszy artykut.
\end{abstract}

Słowa kluczowe: człowiek stary, wykluczenie, reintegracja społeczna, społeczeństwo aktywizacja.

\section{Wstęp}

Starość... towarzyszy człowiekowi od momentu jego narodzin. W zależności od epoki była pożądana, niepokojąca, obciążająca, wprowadzająca w zażenowanie, czy wreszcie wzbudzająca agresję. Pozycja osób starszych w poszczególnych kulturach i epokach ulegała ciągłym zmianom. Postęp cywilizacyjny, rewolucja przemysłowa, a za nim rewolucja kulturowa, doprowadziły do pojawienia się

* Małgorzata Duda - dr hab., Uniwersytet Papieski Jana Pawła II w Krakowie. 
postaw skrajnie odmiennych, jeżeli chodzi o zachowania wobec nestorów żyjących w rodzinie polskiej. Jaka jest przyszłość starzejącego się społeczeństwa? Dane statystyczne nie pozostawiają złudzeń - na koniec 2015 roku, prawie 1/4 społeczności Polaków to osoby w wieku 60 lat i więcej, przy czym populacja osób w przedziale wiekowym 60-64 lat, w przeciągu ostatniego ćwierćwiecza, wzrosła o połowę. Według danych GUS, w kolejnych latach nadal będzie rosnąć udział tej grupy osób w całej populacji Polaków. Niestety, nie dla wszystkich będzie to życie w zdrowiu. Samoocena stanu zdrowia seniorów plasuje się w kategorii „tak sobie". Dominują choroby przewlekłe, charakterystyczne dla starszych osób, coraz słabsza mobilność, czy postępujące ograniczenia w codziennym funkcjonowaniu. Oczywiście stan zdrowia osób starszych pogarsza się wraz z wiekiem - „na 1 osobę z grupy 60-69 lat przypadało tylko 3,1 chorób przewlekłych, czy dolegliwości, wśród siedemdziesięciolatków już 4,1, a wśród osób najstarszych - 4,5”' . Niewiele lepiej kształtuje się sytuacja populacji seniorów pod względem niepełnosprawności. Na koniec 2014 roku co druga osoba 60+ została zaliczona do grupy osób niepełnosprawnych biologicznie, czyli takich, które z powodu problemów zdrowotnych miały ograniczoną zdolność wykonywania najczęstszych życiowych czynności. Jednocześnie nadal odnotowuje się wydłużony czas oczekiwania na porady lekarzy - specjalistów, utrudniony jest dostęp do usług rehabilitacyjnych, czy świadczeń opiekuńczych. Osoby wymagające całodobowej opieki coraz częściej stają się mieszkańcami domów pomocy społecznej. Liczba osób starszych objętych opieką instytucjonalną świadczącą usługi pomocy społecznej wzrosła o 8,7\%. Ostatnie dane statystyczne za rok 2015 wskazują na wzrastającą liczbę świadczeń psychogeriatrycznych o ponad 3,6 mln złotych w stosunku do roku poprzedniego. Mimo wzrostu liczby podmiotów świadczących usługi geriatryczne, ich dostępność jest daleka od bezwzględnie koniecznych. Niedobory mają zarówno wymiar ilościowy (niewystarczająca liczba lekarzy i pielęgniarek), jak i terytorialny².

W prawie połowie gospodarstw domowych w Polsce mieszkała przynajmniej jedna osoba starsza. Według danych Spisu Powszechnego z 2011 roku, spośród wszystkich gospodarstw domowych, których członkami były osoby starsze, zdecydowana większość mieszkała samodzielnie. W prawie $50 \%$ osoby starsze $(60+)$ mieszkały same, czyli w ich gospodarstwie domowym nie mieszkał nikt młodszy³.

\footnotetext{
Informacja Ministra Zdrowia na temat wpływu zmian demograficznych i starzenia się społeczeństwa na organizację systemu ochrony zdrowia i Narodowy Program Zdrowia, GUS, www.stat.gov.pl [dostęp 20.02.2017 r.].

2 Informacja o sytuacji osób starszych w Polsce za rok 2015, www.senior.gov.pl, [dostęp 24.02.2017 r.].

Tamże, s. 43.
} 
Populacja osób 60+ w 2015 roku stanowiła 6,1\% ogółu aktywnych zawodowo. Z kolei, osoby bierne zawodowo to 87,5\% ogółu ludności 60 lat i więcej. Wśród głównych przyczyn bierności zawodowej, respondenci wskazywali emeryturę, chorobę lub niepełnosprawność. Postępująca starość ma twarz kobiety - wśród osób $60+$ żyje w małżeństwie $78 \%$ mężczyzn i 42\% kobiet, natomiast w wieku sędziwym aż $2 / 3$ populacji to osoby owdowiałe, w tym $90 \%$ to kobiety ${ }^{4}$. W interesującym nas temacie aktywności społecznej odnotowuje się wysoki wskaźnik izolacji społecznej, który na koniec 2015 roku wyniósł 10,6 w stosunku do 7,6 dla osób w przedziale wiekowym 16-595. Oznacza to, że co dziesiąta osoba starsza ma ograniczone kontakty społeczne.

\section{Senior w przestrzeni społecznej}

Osoba starsza to ta, która m.in. wkroczyła w próg kalendarzowy wyznaczony uprawieniami do świadczenia emerytalnego (obecnie 67 lat, od października 2017 roku dla kobiet - 60 lat, dla mężczyzn - 65 lat), wiek biologiczny (związany ze sprawnością organizmu do zapewnienia samodzielności), próg społeczny (utrata dotychczasowych ról społecznych i prestiżu), próg ekonomiczny (związany ze znacznym zmniejszeniem zasobów finansowych), czy próg technologiczny (lęk przed nowoczesnymi urządzeniami) ${ }^{6}$. Jak wspomniano wcześniej, społeczność osób starszych nie jest zbiorowością jednorodną, różnie reaguje na nową życiową sytuację: w większości przypadków zakończona została aktywność zawodowa, pojawiła się olbrzymia ilość czasu wolnego, rozluźnieniu ulegają więzi koleżeńskie z dotychczasowej pracy; maleje liczba znajomych i przyjaciół ze względu na wzrastającą umieralność, wraz z długością życia. Coraz częściej pojawia się refleksja nad dotychczasowym życiem, a jednocześnie osoby starsze stają przed zadaniem podjęcia planów na dalszą przyszłość. Olbrzymią rolę odgrywa tutaj zgromadzone doświadczenie życiowe, które albo było satysfakcjonujące, albo jest postrzegane w kategorii przegranej. Nagle okazuje się, że zarządzanie „nową” fazą życia nie jest rzeczą łatwą. Pojawiają się dolegliwości zdrowotne, na które do tej pory „nie było czasu”, by je rozpoznać; spada aktywność fizyczna i psychiczna; powoli zatraca się poczucie własnej atrakcyjności. Jednym ze szczególnie dojmujących doświadczeń jest poczucie osamotnienia oraz postępująca zależność od osób drugich. Osamotnienie może mieć swoje źródło w naturalnym procesie kończącym życie partnera (współmałżonka); po opuszczeniu przez dzieci domu

4 Tamże, s. 42.

5 Tamże, s. 70.

6 Wybrane problemy osób starszych, red. A. Nowicka, Kraków 2006, s. 19. 
rodzinnego (syndrom pustego gniazda), czy w zmianach w psychice osoby starszej, prowadzącej coraz częściej do autodestrukcji.

Zmiany w funkcjonowaniu rodziny współczesnej nie pozostały bez wpływu na pełnione w niej role; na system wartości, jakimi kierują się poszczególni jej członkowie. Dokonujące się rewolucje w kulturze, w społeczeństwach, odcisnęły piętno na kształcie życia w niemal każdym wymiarze: pojawiły się próby redefinicji rodziny, małżeństwa; definicji płci; ról społecznych; zmiany w relacjach międzyludzkich ${ }^{7}$. Zarówno przedstawiciele różnych dyscyplin naukowych, jak i Kościół katolicki wyraźnie wskazują na istniejący kryzys instytucji rodziny. Pośród wielu wskaźników wymienia się: brak prostej zastępowalności pokoleń w wyniku spadku urodzeń (wskaźnik ten, na koniec 2013 roku wyniósł 1,29), upowszechnianie się życia w związkach nieformalnych, wzrost urodzeń pozamałżeńskich (ponad 20\%), aborcja; niespotykany wzrost rozwodów ${ }^{8}$; przemoc, indywidualizm i relatywizm, nieobecność ojców, samotność, porzucanie osób starszych i zaniedbywanie funkcji opiekuńczej wobec dzieci (zjawisko bezdomności dzieci), czy wszechobecne zarobkowe migracje niszczące rodziny ${ }^{9}$. Przemian wewnątrzrodzinnych doświadczają również osoby starsze. Ich pozycja w rodzinie zmienia się wraz z przyjętym modelem życia rodzinnego.

Rodziny wielopokoleniowe, w których możliwy jest pełniejszy rozwój seniora, są dzisiaj rzadkością i częściej spotykane są w środowiskach wiejskich. Nie oznacza to, że miejsce nestora rodu podobne jest do jego poprzedników. Zmieniające się społeczeństwo wymusza dostosowanie się do tych zmian, gdyż w rodzinie, niczym w soczewce, skupiają się przeobrażenia, jakie zachodzą w szerszej przestrzeni życia. Wszechobecna zmiana wymusza na poszczególnych członkach rodziny dostosowanie się do nich, w przeciwnym przypadku istnieje niebezpieczeństwo pozostania na uboczu.

Obok tradycyjnych ról babci i dziadka oraz wsparcia własnym autorytetem młodych, współczesna osoba starsza jawi się jako osoba aktywna, bądź pasywna

7 T. Biernat, Czy istnieje rodzina ponowoczesna?, „Pedagogia Christiana” 2014, nr 2 (34), s. 185.

8 W 2013 roku orzeczono ich około 66 tys. (tj. o 24 tys. więcej niż w 1990 roku); współczynnik rozwodów wyniósł 1,7\%o (w 1990 roku wynosił 1,1\%o). W 2013 r. na każde 10 tys. istniejących małżeństw 73 zostały rozwiązane orzeczeniem sądu, podczas gdy na początku lat 90. było ich niespełna 50, GUS, stat.gov.pl/download/gfx/.../pl/.../5468/23/.../ malzenstwa_i_dzietnosc_w_polsce [dostęp 3.03.2017 r.].

9 „Relatio Synodi” III Nadzwyczajnego Zgromadzenia Ogólnego Synodu Biskupów: Wyzwania duszpasterskie dla rodziny w kontekście nowej ewangelizacji, 5-12 października 2014 roku, http://bit.ly/snr18-3-12 [dostęp 3.03.2017 r.]. 
społecznie. W zależności od dotychczasowego trybu życia, zdrowia i samoakceptacji nowej sytuacji zależy jakość kolejnego etapu życia. Jednak jest to proces, który wymaga odpowiedniego przygotowania do starości. Szczególnie istotnym jest podejście psychiczne, relacje $\mathrm{z}$ najbliższymi oraz $\mathrm{z}$ otoczeniem. Osobom starszym nie jest łatwo zaaprobować nową rzeczywistość. Jedni rzucają się w wir zróżnicowanych aktywności, inni - po początkowym zadowoleniu z nadmiaru wolnego czasu - wpadają w apatię, depresję, czy lęk przed tym, co nieznane. Dotyczy to zwłaszcza osób samotnych, o niskich uposażeniach (a więc bez poczucia bezpieczeństwa finansowego), w złej kondycji zdrowotnej. W sytuacji tych drugich niezwykle ważną rolę odgrywa społeczeństwo, ze swoją wrażliwością na potrzeby innych, mając odpowiednie narzędzia wsparcia.

Jednocześnie starość niesie ze sobą olbrzymi bagaż doświadczenia, szczególnie cenny w sytuacji zwiększającej się liczby osób starszych, przy jednoczesnym kurczeniu się populacji osób w wieku produkcyjnym. Jak podaje T. Schimanek, „osoby starsze to ogromny potencjał, który może i powinien być wykorzystany przez organizacje pozarządowe i społeczności lokalne. To przede wszystkim nieocenione źródło tak zwanej wiedzy pragmatycznej, czyli wiedzy budowanej na podstawie długoletnich życiowych i zawodowych doświadczeń. To także umiejętności praktyczne, przydatne innym, czy też czas, który osoby starsze mogą poświęcić na pracę w organizacji pozarządowej, czy społeczności lokalnej”10.

\section{Aktywność w starości}

Mimo że aktywna starość jest nadal czymś nowym w rzeczywistości polskiej, to powoli zmienia się postrzeganie osób starszych w przestrzeni społecznej. Przedłużenie dotychczasowej aktywności, zarówno tej związanej z pracą zawodową, jak i społeczną stanowi istotny element kondycji psycho-fizycznej. Dzięki niej osoby starsze nadal czują się wartościowe, potrzebne; motywują się do dbania o swoje zdrowie, swój wygląd zewnętrzny; nadal utrzymują kontakty interpersonalne, szczególnie istotne dla osób samotnych. Aktywność daje szansę na utrzymanie większości dotychczasowych ról społecznych, utrzymanie prestiżu, a co za tym idzie pozytywnego obrazu seniora, mającego wpływ na swoje życie i społeczności, w której żyje. M. Dzięgielewska wyróżnia trzy typy aktywności seniorów:

- formalną - uczestnictwo w polityce, organizacjach i stowarzyszeniach, wolontariacie, czy na rzecz środowiska lokalnego;

10 T. Schimanek, Aktywizacja społeczna osób starszych. Materiaty edukacyjne dla pracowni dobra wspólnego, http://bit.ly/snr18-3-13, [dostęp 12.03.2017 r.]. 
- nieformalną - polegającą na relacjach rodzinnych, przyjacielskich, sąsiedzkich;

- $\quad$ samotniczą - sprowadzająca się do spędzania czasu wolnego w tradycyjny sposób (oglądanie TV, słuchanie radia, czytanie książek, realizację własnego hobby ${ }^{11}$.

Osoby starsze chcą być aktywne, szczególnie cenią sobie kontakty z najbliższymi. Zdają sobie sprawę z wartości swojego doświadczenia życiowego, którym chcą się dzielić z młodszym pokoleniem. Doceniają także relacje ze swoimi wnukami, upatrując $\mathrm{w}$ nich pomocników do poznania obsługi np. nowych technologii. W wymianie międzypokoleniowej dochodzi do realizacji obopólnych potrzeb. Seniorzy chcą pozostać w obszarze życia swoich dzieci i wnuków, mobilizują się do nowych aktywności. A dzieci i wnuki zdobywają tak cenne informacje o doświadczeniach poprzednich pokoleń. Wspólne, pokoleniowe rozmowy, w których poznaje się historię, tak rodziny, jak i narodu, ubogacają wszystkich, jednocześnie zapewniając poczucie bezpieczeństwa. Seniorzy czują się w obowiązku wspomagać swoje dorosłe dzieci w ich codziennych obowiązkach, zwłaszcza w prowadzeniu gospodarstwa rodzinnego, często wspomagając finansowo. Jeżeli osoby starsze mają $\mathrm{w}$ miarę stabilną sytuację materialną i są w tym względzie samodzielne, postrzegani są przez pozostałych członków rodziny jako współpartnerzy, równoprawni w podejmowaniu ważnych dla rodziny decyzji ${ }^{12}$.

Inną grupę stanowią osoby starsze - zaangażowane społecznie, politycznie, czy kulturowo. Nie od dzisiaj wiadomo, że osoby starsze są świadomymi wyborcami. Interesują się polityką, a podczas wyborów stają się „cennym” elektoratem. Poszczególni kandydaci do stanowisk politycznych rywalizują o głosy seniorów, którzy często padają ofiarami manipulacji w tym obszarze, ze względu na swoją otwartość, zaufanie, jakim obdarzają ludzi. Elektorat seniorów jest zdyscyplinowany, świadomy ważności wyborów i odpowiedzialności za państwo, dlatego udział osób starszych w wyborach jest zawsze wysoki. Jedynie zły stan zdrowia może ograniczyć czynny udział w głosowaniu, ale i dzisiaj jest to przeszkoda, którą można pokonać dzięki m.in. zmianom w przepisach prawa wyborczego o udziale osób zależnych (starszych, niepełnosprawnych) w tych czynnościach ${ }^{13}$. W ostatnich

11 Podaję za: M. Kaczmarczyk, E. Trafiałek, Aktywizacja osób w starszym wieku jako szansa na pomyślne starzenie się, „Gerontologia Polska” 2007, nr 4, s. 116-117.

12 M. Posłuszna, Aktywność rodzinna i społeczna osób starszych, „Nowiny Lekarskie” 2012, nr 1 (81), s. 76-77.

13 Szerzej: Gwarancje korzystania z czynnego prawa wyborczego przez osoby starsze i osoby z niepetnosprawnościami, red. J. Zbieranek, „Biuletyn Rzecznika Praw Obywatelskich" 2012, nr 4, s. 9-23. 
latach obserwuje się powolny rozwój innych form, w których aktywizują się seniorzy. Dobrym przykładem są Uniwersytety Trzeciego Wieku, które oferują zróżnicowaną ofertę edukacyjną, kulturalną, czy rekreacyjną. Jednakże to tylko kropla w morzu potrzeb. Według danych statystycznych liczba UTW kształtowała się w 2016 roku w granicach $613^{14}$, z tendencją wzrostową. Najliczniejszą grupę zaangażowanych w zajęciach UTW stanowią seniorzy w wieku 60-65 lat (33\%), 66-70 lat (29\%), czy osoby powyżej 75 roku życia - 11\%. Prężnie rozwijają się Kluby Seniora, Centra Seniorów, popularnością cieszą się programy skierowane do aktywnych seniorów na wsi (realizowane m.in. przez Domy Kultury, Koła Gospodyń Wiejskich). Chętnie angażują się w różnych formach działalności kulturalnej. Dane statystyczne pokazują, że na koniec 2014 roku osoby w wieku 60+ stanowiły 18,5\% ogólnej liczby członków zespołów i grup artystycznych; szczególną popularnością cieszą się zespoły folklorystyczne - ponad 33\% uczestników to właśnie seniorzy ${ }^{15}$. Seniorzy uczestniczą $\mathrm{w}$ programach na rzecz środowiska lokalnego. Stosunkowo wielu z nich uczestniczy w działalności na rzecz organizacji religijnych o charakterze charytatywnym; angażują się w wolontariat, także na rzecz wsparcia rówieśników. Szczególnie istotne są grupy samopomocowe, ponieważ nikt tak nie zrozumie potrzeb seniorów, jak osoba w podobnym wieku, z podobnymi doświadczeniami życiowymi. Wolontariusz-senior staje się wtedy osobą wiarygodną, godną zaufania.

Aktywny senior to także osoba, która chętnie korzysta ze zróżnicowanej oferty kursów i szkoleń jej dedykowanych. Szczególnym zainteresowaniem cieszą się kursy komputerowe (62\% wszystkich uczestników to seniorzy), kursy językowe $24,6 \%$ oraz kursy wiedzy praktycznej, w których uczestniczyło 19,5\% osób starszych. Co piąta osoba uczestnicząca w podróżach to senior, jednak zdecydowana większość z nich to mieszkańcy miast. Miarą aktywności osób starszych jest także edukacja w starości. Niestety, Polska zajmuje jedno z ostatnich miejsc w Europie pod tym względem. Udział populacji seniorów w kształceniu i szkoleniach wyniósł zaledwie $0,6 \%$, przy średniej 4,8\% w UE ${ }^{16}$.

Nadal najliczniejszą grupą seniorów są osoby mało aktywne. Ich zaangażowanie sprowadza się do spędzania czasu wolnego poprzez oglądanie telewizji, słuchanie radia, czytelnictwo. Przyczyn takiego stanu rzeczy można szukać m.in. w braku rozwiniętej potrzeby poszukiwania innych sposobów spędzania czasu;

14 Dane Federacji UTW z sierpnia 2016 roku, http://www.federacjautw.pl/index.php/ baza-utw [dostęp 20.03.2017 r.].

15 Informacja o sytuacji osób starszych w Polsce za rok 2015, www.senior.gov.pl, s. 7778 [dostęp 10.03.2017 r.].

16 Tamże, s. 74, 78-79. 
stan zdrowia; postrzeganie roli osoby starszej w społeczności zamieszkania; utrudniony dostęp do istniejącej oferty kulturalnej, czy edukacyjnej; brak zrozumienia ze strony najbliższych.

Wśród innych, ważnych zagrożeń, jakie ograniczają, czy wręcz niekiedy uniemożliwiają aktywne przeżywanie starości, wskazuje się przeżywanie straty po śmierci współmałżonka. Zdarza się, że okres żałoby pozostaje z osobą owdowiałą do końca życia.

Stres to kolejne zagrożenie, które może prowadzić do rozwoju chorób psychicznych, depresji, prób samobójczych. Osoby starsze, samotne, z zaniżoną samooceną, niezadowolone $\mathrm{z}$ dotychczasowego życia boją się nadchodzącej starości, a kiedy przechodzą na emeryturę - nie potrafią pogodzić się z tą sytuacją. Stres, wywołany strachem, doprowadza w sytuacjach skrajnych do sytuacji zagrażających zdrowiu i życiu.

Istotnym czynnikiem zagrażającym współczesnym seniorom jest przemoc. Przemoc wobec starszych jest stosowana zarówno w środowisku rodzinnym (domowym), instytucjonalnym środowisku opiekuńczym i leczniczym, jak również środowisku lokalnym, w miejscu zamieszkania. W obszarze przemocy bezpośredniej wskazuje się przemoc fizyczną, seksualną, psychiczną czy emocjonalną. Przemoc fizyczna, popychanie, zmuszanie do jedzenia czy głodzenie, poniżanie, lekceważenie czy nieuprawnione dysponowanie majątkiem to tylko niektóre z przykładów przemocy bezpośredniej. Przemoc instytucjonalna, systemowa jest wyjątkowo trudna do zrozumienia. Opracowane rozwiązania systemowe mające na celu wspieranie osób starszych w trudnych momentach życia, w skrajnych przypadkach obracają się przeciw nim. Niewłaściwe wypełnianie obowiązków w placówkach opieki zdrowotnej, placówkach opieki całodobowej, instytucjach administracji publicznej, samorządowej, czy organach wymiaru sprawiedliwości to tylko niektóre przykłady przemocy systemowej. Wreszcie samo społeczeństwo, z przyjętymi wzorcami kulturowymi, nieprzyjaznymi seniorom, generują postawy nieprzyjazne osobom starszym, odmawiając im wręcz prawa do życia ${ }^{17}$. Niemniej istotnym, i wydaje się zasadniczym zagrożeniem dla współczesnego seniora jest on sam. W przypadku braku mentalnego przygotowania się do własnej starości i poczynionych wcześniej kroków w tym kierunku (np. zabezpieczenie finansowe, dbałość o stan zdrowia, pomysł na zagospodarowanie nowej fazy w życiu), wszelkie zabiegi aktywizacji czynione „,z zewnątrz”, przez społeczeństwo, nie przyniosą oczekiwanego rezultatu.

17 Szerzej: J. K. Wawrzyniak, Przemoc wobec osób starszych. Diagnozowanie zjawiska i strategie pomocowe, w: Starzenie się i starość w perspektywie pracy socjalnej, red. A. Chabior, A. Fabiś, J. K. Wawrzyniak, „Nowa Praca Socjalna” 2014, nr 12, s. 95-101. 


\section{Zakończenie}

Przyglądając się społeczności seniorów oraz zróżnicowanym formom ich aktywizacji, w celu zapobieganiu wykluczeniu, nie sposób zauważyć, że zdecydowana większość pozostaje na uboczu lub uaktywnia się sporadycznie. Aktywnymi pozostają ci, którzy byli takimi wcześniej. Widać wyraźne zróżnicowanie terytorialne - bardziej aktywizują się seniorzy zamieszkali w miastach, ze średnim lub wyższym wykształceniem, rzadziej widać to zjawisko na wsi. Gdzie więc szukać możliwych rozwiązań? Czy istnieją skuteczne sposoby przeciwdziałające tej bierności? W jaki sposób przeciwdziałać dyskryminacji ze względu na wiek? Oczywistym jest, że nie można dać jednoznacznej odpowiedzi na tak postawione pytania, jednak można próbować wskazać swoiste drogowskazy, mogące przynieść pozytywną zmianę. Jednym z nich jest właściwie kształtowana polityka senioralna państwa, oparta na prawie osoby starszej ,do godnego i niezależnego życia oraz uczestnictwa w życiu społecznym i kulturalnym"18. Senior musi się czuć bezpiecznie w społeczności, w której żyje; musi postrzegać siebie jako integralną jej część. Z pomocą przychodzi zasada dobra wspólnego, w myśl, której nie tylko społeczeństwo zobligowane jest do wspierania jednostki, ale także członek tej społeczności winien brać współodpowiedzialność za jej losy. Zasada dobra wspólnego daje więc konkretne uprawnienia dla członków społeczeństwa, jak również wzywa do podejmowania wysiłków do jej budowania i podtrzymywania w prawidłowym funkcjonowaniu. Osoby starsze ze swym doświadczeniem winny stanowić istotne ogniwo w utrzymaniu tej zasady. Dzięki zasadzie pomocniczości (subsydiarności) oraz powiązanej z nią zasadzie solidarności, obywatele nabywają praw do kreowania rzeczywistości państwa, na wszystkich jego szczeblach. Dopuszczenie osób starszych do współdecydowania w zarządzaniu społecznością lokalną to istotny element aktywnego uczestnictwa w życiu społecznym. Człowiek mający poczucie sprawstwa, chętniej podejmie wyzwanie czynnego uczestnictwa w jej budowaniu ${ }^{19}$.

Powyższe sugestie zdają się jednak być mało przekonujące dla samych osób starszych. Obserwuje się zależność, w której seniorzy aktywni w życiu zawodowym pozostają aktywnymi i po przejściu na emeryturę. Korzystają z ciekawych ofert przygotowanych dla nich przez różne podmioty rządowe, samorządowe, czy pozarządowe. Jednakże statystyki wykazują, iż procentowy udział seniorów w tych działaniach nie jest zadowalający. Dotyczy to zwłaszcza osób samotnych

18 Artykuł nr 25 Karty praw podstawowych Unii Europejskiej, http://bit.ly/snr18-3-14 [dostęp 12.03.2017 r.].

19 A. Chabior, A. Fabiś, J. K. Wawrzyniak, Starzenie się i starość w perspektywie pracy socjalnej, „Nowa Praca Socjalna” 2014, nr 12, s. 19-20. 
i mieszkańców wsi. Zarówno sami seniorzy, jak i osoby z nimi i na ich rzecz pracujący wskazują na kilka kwestii, które pomogą przełamać to swoiste „błędne koło”. Istnieje słaba promocja programów dedykowanych seniorom. Osoby starsze nie mają dostatecznej wiedzy na temat ich istnienia, możliwościach uczestnictwa itp. Wielu seniorów (zwłaszcza samotnych) chce się aktywizować, dzielić się swoim czasem z innymi, ale nie ma dostatecznej wiedzy, gdzie można się zaangażować. Innym postulatem jest propagowanie działalności seniorów już aktywnych. Przykłady tzw. dobrych praktyk to przekonujący argument dla innych osób starszych, że warto pokonać swoje obawy, warto zwalczyć nieuzasadniony strach przed nieznanym i zaangażować się w działania, które w efekcie końcowym przyniosą zysk im samym. Także samo społeczeństwo wymaga głębokiej rewizji podejścia do swoich seniorów. Myślenie o osobach starszych albo w kategorii osób zależnych, trudnych we współżyciu albo osób lekko traktujących swoje zobowiązania wobec rodziny i państwa, nie pozwala na dostrzeżenie, jak populacja seniorów wygląda rzeczywiście. W sposób błędny odczytujemy ich potrzeby, określamy ich możliwości, zasoby, jakimi dysponują. Co więcej, nieprzychylny obraz osób starszych w mediach, nie pozwala dokonać rzetelnej weryfikacji i przyczynia się do dalszego wycofania się i samoizolacji.

Zarówno społeczeństwo, jak i sama populacja osób starszych postrzega i opisuje seniorów w dwojaki, skrajnie odmienny sposób. Przełamanie tych przeciwności to pierwszy i wydaje się podstawowy sposób dający podstawę do zmiany niekorzystnej sytuacji. Wprowadzenie przemyślanej polityki senioralnej, w ramach polityki społecznej państwa, z uwzględnieniem głosów samych zainteresowanych może stanowić punkt zwrotny do wykorzystania drzemiącego potencjału seniorów w Polsce. To ważne podkreślenie, by o przyszłości narodu, w znaczącej mierze złożonego z osób starszych, mogli decydować sami zainteresowani, w myśl powiedzenia „nic o nas - bez nas”.

O znaczeniu osób starszych pisał Jan Paweł II w Liście do braci i sióstr ludzi w podeszłym wieku. Dzięki nim społeczeństwo może mądrze patrzeć na współczesne wydarzenia, a dzięki zgromadzonej wiedzy stają na straży historii. Działania zmierzające do wykluczenia ich z przestrzeni społecznej to nic innego jak, w imię źle pojętej nowoczesności, odrzucanie przeszłości - fundamenty teraźniejszości i przyszłości ${ }^{20}$.

20 Jan Paweł II, List do moich braci i sióstr - ludzi w podeszłym wieku, Poznań 1999, nr 10. Także: M. Brzeziński, O czci i szacunku wobec ludzi starszych na kanwie Listu do osób w podeszłym wieku Jana Pawła II, „Roczniki Nauk o Rodzinie i Pracy Socjalnej” 2012, nr 4 (59), s. 262-264. 


\section{Bibliografia}

Artykuł nr 25 Karty praw podstawowych Unii Europejskiej, http://eur-lex.europa. eu/legal-content/PL/TXT/?uri=celex\%3A12012P\%2FTXT [dostęp 12.03.2017 r.]. Biernat T., Czy istnieje rodzina ponowoczesna?, „Pedagogia Christiana” 2014, nr 2 (34), s. 185.

Brzeziński M., O czci i szacunku wobec ludzi starszych na kanwie Listu do osób w podeszłym wieku Jana Pawła II, „Roczniki Nauk o Rodzinie i Pracy Socjalnej” 2012, nr 4 (59), s. 253-266.

Chabior A., Fabiś A., Wawrzyniak J.K., Starzenie się i starość w perspektywie pracy socjalnej, 2014.

GUS, Informacja Ministra Zdrowia na temat wptywu zmian demograficznych i starzenia się społeczeństwa na organizację systemu ochrony zdrowia i Narodowy Program Zdrowia, www.stat.gov.pl [dostęp 20.02.2017 r.].

Gwarancje korzystania z czynnego prawa wyborczego przez osoby starsze i osoby z niepetnosprawnościami, w: Biuletyn Rzecznika Praw Obywatelskich, red. J. Zbieranek, 2012, nr 4.

Informacja o sytuacji osób starszych w Polsce za rok 2015, www. senior.gov.pl, s. 77-78 [dostęp 10.03.2017 r.].

Jan Paweł II, List do moich braci i sióstr - ludzi w podeszłym wieku, Poznań 1999. Kaczmarczyk M., Trafiałek E., Aktywizacja osób w starszym wieku jako szansa na pomyślne starzenie się, „Gerontologia Polska” 2007, nr 4, s. 116-118.

Posłuszna M., Aktywność rodzinna i społeczna osób starszych, „Nowiny Lekarskie” 2012, nr 1 (81), s. 75-79.

„Relatio Synodi” III Nadzwyczajnego Zgromadzenia Ogólnego Synodu Biskupów: Wyzwania duszpasterskie dla rodziny w kontekście nowej ewangelizacji, 5-12 października 2014, http://kosciol.wiara.pl/doc/2213827.Relacja-IIINadzwyczajnego-Synodu-Biskupow [dostęp 3.03.2017 r.].

Schimanek T., Aktywizacja społeczna osób starszych. Materiaty edukacyjne dla pracowni dobra wspólnego, http://mrs.poznan.pl/schimanek-tomasz-aktywizacja-spoleczna-osob-starszych-materialy-dla-pracowni-dobra-wspolnego/, [dostęp 12.03.2017 r.].

Wybrane problemy osób starszych, red. A. Nowicka, Kraków 2006 
Malgorzata Duda: A few words about the activity elderly people

\begin{abstract}
Summary
Last years brought the state's stronger action to introduce and implement the active social policy. One observes the actions undertaken to integrate communities facing the threat of social exclusion, as well as activities which are supposed to turn the groups already excluded, marginalised into society. Elderly people belong to such a group and are the target of the activated actions of social policy. The senior population itself is internally diversified, thus one should expect that the activation offer shall be diversified as well. However, does it happen in reality? Do the organised forms of work with and for elderly people are appropriate, do they reach an intended effect? Moreover: if it is so good, why is it so bad? Where one should search for sources of failures? These are only some questions, to whichindeed casually - the article will try to answer.
\end{abstract}

Keywords: elderly man, exclusion, social reintegration, society, activation. 